\title{
NARRATIVES ON FOLK HEALING IN BATO, CAMARINES SUR
}

\author{
Mark Philip C. Paderan \\ Instructor \\ College of Liberal Arts \\ University of Saint Anthony
}

\begin{abstract}
This study on indigenous healing practices because of the interesting fact that despite the presence of medical advancement, there are still people who have the tendency to consult first a folk healer before seeking the help of modern medical practitioners. And what makes it more interesting is that even professionals seek for the help of folk healers. We may have choices on whom to seek and where to go when we have physical ailments but in this age of modern technology, why such healing tradition continues to exist and co-exist with modern medicine remains a baffling question.

But these questions were given answers through this research which aimed at probing into the narratives of the healers and their patients on the curative properties and healing remedies of an age-old tradition. Thus, this is a humble endeavor to sustain the perpetuation of Bicol culture and tradition focusing on the stories on folk healing traditions in order to record, preserve and understand the functions in the society of these indigenous age-old healing practices that are struggling to survive yet undeniably at the brink of extinction.

The study focused on the collection, translation, and analysis of folk healing narratives in the selected barangays of Bato, Camarines Sur. The study would like to answer the following questions: (1) What types of indigenous healing practices are evident in the narratives? (2) What do these narratives relate in terms of: (a) Abstract/summary; (b) Orientation in terms of time, place, person, situation; (c) Complicating action; (d) Evaluation; (e) Resolution/Result. (3) What roles in the community do these folk healing narratives reveal? (4) What educational material could be produced to preserve and showcase these indigenous healing practices?

With regard to the scope of the study, it focused on narratives on traditional healing in the barangays of Bato, Camarines Sur namely; Divina Pastora, Tres Reyes and Santa Cruz being the most densely populated barangays in the roadside of Bato, Camarines Sur. The study gave emphasis on the first-hand information based on the personal experiences of the key informants who will be composed of the healers and their patients. It delimited itself to the collection, translation, and analysis of the narratives on folk healing practices and not mainly on the rituals and processes involve in healing.

Further, this study has the intention to benefit some sectors of the society such as the people of Bato; the Local Government Unit of Bato, Camarines Sur; Camarines Sur itself; students who are taking English, Literature and Social Sciences; medical
\end{abstract}




\section{Ahmad Dahlan Journal of English Studies (ADJES)}

Vol. 3, Issue 1, March 2016

practitioners, the folk healers themselves and future researchers who would like to undergo a study of the same kind and to the researcher himself.

To give you an overview of the study, let me explain its Analytical Paradigm:

Every individual is by nature a social being that cannot be hindered from having interaction with their co-human beings. Whenever human beings meet, they mingle with each other and share the same needs, practices, beliefs, customs and even expressions; and create a community that comprises a society.

In every society, a culture is born and creates an influence in the entire community. Culture and society are intricately and closely related. We cannot really have one without another because people in a society developed its own culture; culture that shapes the way they interact with one another and understand the world around them.

People sharing the same way of living may have common occupation, language, ethnicity, age, or geographical location. There were stories or narratives that emerged in the past which only shows that a group of individuals has the capacity to produce their own literature which they transmit orally or by means of body language.

Focusing on Literature, literary scholars claim that literature does not delimit itself to written records rather includes oral traditions that date back to the ancient or prehistoric times. One of the oldest forms of literature is folklore since it showcases the earliest forms of expressive culture such as music, dance, legends, oral history, proverbs, jokes, beliefs, customs and practices within a particular group of people.

Folklore, being the earliest form of literature embraces at the same time folk healing as the oldest form of structured medicine. This study centered on folk healing narratives to identify the types of folk healing in selected barangays of Bato, Camarines Sur as well as their functions in the society.

This study is anchored on William Bascom's theory, one of the earliest proponents of functionalism, which claims that folklore is an important mechanism for maintaining the stability of culture and he states that every society creates its own culture and literature. The data is to be collected using Goldstein's ethnographic approach. Using this method of data gathering, the researcher is expected to undergo immersion, participant-observation and unstructured interviews within the target locale to be in direct contact with the key informants of the study. After collecting the data needed, they were translated in English.

After the collection and translation of data, the folk healing narratives were validated through Arsenio Manuel's vertical and horizontal tests. The vertical test were used to determine if the narratives or knowledge on indigenous healing 
have passed through at least three generations of narrators/storytellers while the horizontal test were employed to identify the presence of at least five variants of a text within the locale of the study to prove the folkloricity of the narratives.

The data were analyzed using descriptive content analysis and the Labovian Method of narrative analysis that served as guide in the analysis of the structure which includes: a) abstract/summary; b) orientation in terms of time, place, person, and situation; c) complicating action; d) evaluation; e) resolution/result; and f) coda.

After which, the narrative elements behind indigenous healing practices were carefully examined and the researcher determined the functions of the healing practices in the society using functionalism approach. The study was also able to discern the significance of such tradition to modern times, thereby promoting greater awareness and appreciation of one's indigenous roots through the study of healing practices.

An educational material is the output of the study which will be useful in preserving and showcasing the indigenous healing practices.

After having carefully examined the narrative elements behind indigenous healing practices, the researcher was able to discern the significance of such tradition to modern times thereby promoting greater awareness and appreciation of one's indigenous roots through the study of healing practices.

After going through the process of collecting, translating, analyzing, and interpreting the narratives on folk healing in Bato, Camarines Sur, the study revealed the following findings in which conclusions were drawn:

\section{Findings}

1. There were 28 folk healing narratives gathered from the three (3) barangays of Bato, Camarines Sur. These narratives were classified into two major categories: the narratives of the healers, which talk about the types of healing, and the narratives of the clients/healed, which deal with stories on folk illnesses.

There were a total of ten (10) narratives from folk healers themselves which were evaluated and classified into five (5) types: 1. Two (2) folk healing narratives on "Ukag", 2. Two (2) folk healing narratives on "Sibang", 3. Two (2) folk healing narratives on "Pagmundag", 4. Two (2) folk healing

\section{Conclusions}

1. The types of indigenous healing practices revealed by the narratives are: "Ukag", "Sibang", "Pagmundag", "Santigwar", and "Pray-Over". These healing practices were also used to heal the illnesses of people in the societies because of following causes: "Lupo", "Sibang", "bughat", Accident and Natural Illness, Bewitching or "Naibanan". 
narratives on "Santigwar", and 5. Two (2) folk healing narratives on "PrayOver".

On the other hand, there was a total of 18 narratives from clients who were healed by folk healers. These narratives of the healed were studied and classified into six (6) types: 1. Narratives on "Ukag", 2. Narratives on "Sibang", 3. Narratives on "Santigwar", 4. Narratives on "Nabughat", 5. Narratives caused by Accident and Natural Illness", 6. Narratives on Bewitching or "Naibanan".

The twenty-eight (28) narratives from both categories passed the five (5)-version horizontal test while there were only nine (9) narratives which passed the test and there were nineteen (19) narratives which failed the three (3) generation vertical test. Through the Manuel's horizontal test, the narratives were used validated where folkloricity of the narratives by producing five adaptations/versions known by a number of persons within the same locale who could also narrate or retell the story. However, most of the narratives failed the three (3) generation vertical test which can be concluded that folk healing is more of a gift from a supernatural being than a skill that can be trained. Furthermore, healers treats their information on healing with utmost confidentiality that not all of the healers cannot be passed to the next generation unless with permission or told by supernatural being.

2. Folk narratives has been collected and analyzed using Labovian method which treats personal narratives as a story text and produces structural analyses of specific oral narratives and personal events. The method presents the important components of the method such as the abstract,
2. The narratives gathered from the healer and from the clients/healed were all complete and considered as fully-formed because they all follow the abstract-orientation-complicating action-evaluation-resolution which are significant for the collection of the information both from the healers and 


\begin{tabular}{|c|c|}
\hline $\begin{array}{l}\text { orientation, complicating action, } \\
\text { evaluation and resolution. A narrative } \\
\text { that has a complete components would } \\
\text { mean that it has a fully-formed content. } \\
\text { The twenty-eight (28) narratives } \\
\text { gathered from the healer and from the } \\
\text { clients/healed were all complete and } \\
\text { considered as fully-formed because } \\
\text { they all follow the abstract-orientation- } \\
\text { complicating action-evaluation- } \\
\text { resolution which are significant for the } \\
\text { collection of the information both from } \\
\text { the healers and the clients/healed. }\end{array}$ & the clients/healed. \\
\hline $\begin{array}{l}\text { 3. Through the analysis of the } \\
\text { narratives on folk healing using the } \\
\text { elements used, the role/functions of } \\
\text { those were revealed. The folklore gave } \\
\text { emphasis on its importance to the } \\
\text { community giving the community a } \\
\text { reason why these folk narratives should } \\
\text { be promoted and be preserved. a) It } \\
\text { inculcate the values of the society in } \\
\text { the younger generation, frequently } \\
\text { illustrate moral principle where through } \\
\text { the narratives informal teaching can be } \\
\text { done focusing on people's faith in God, } \\
\text { appreciation on culture and educational } \\
\text { material in teaching younger } \\
\text { generations. b) It helps a person find } \\
\text { escape from the repressions imposed } \\
\text { by the society which gives priority in } \\
\text { social relations to avoid individual } \\
\text { anxieties and helps them avoid their } \\
\text { everyday worries in life by sharing their } \\
\text { experiences in healing and expressing } \\
\text { their thoughts and feelings towards life. } \\
\text { c) It stresses the importance of } \\
\text { motivating members of society to } \\
\text { conform to certain behaviors that we } \\
\text { find acceptable which ring to life that } \\
\text { has been forgotten in the aborigine. d) } \\
\text { folklore validates culture which may be } \\
\text { a basis for future references for the } \\
\text { society and researchers. } \\
\text { effective most especially to those who } \\
\text { believe and experienced it. For the }\end{array}$ & $\begin{array}{l}\text { 3. All the functions of folklore in the } \\
\text { society were realized through the } \\
\text { narratives gathered. Most especially in } \\
\text { Education, Escape, Maintaining } \\
\text { Conformity and Validity. Moreover, } \\
\text { Industrialization and modern medicine } \\
\text { may continue to grow and improve but } \\
\text { culture in healing will still continue to } \\
\text { be realized as long as the healers are } \\
\text { there and as long as there are people } \\
\text { who resort to folk healing. }\end{array}$ \\
\hline
\end{tabular}




\begin{tabular}{|c|c|}
\hline $\begin{array}{l}\text { community, resorting to folk healing is } \\
\text { also much cheaper and more practical } \\
\text { for them because of the proximity to an } \\
\text { existing hospital. Moreover, it is a } \\
\text { treasure that is worth keeping and } \\
\text { worth passing from one generation to } \\
\text { another for it is significantly mirrors the } \\
\text { culture of Bikol and Philippines. }\end{array}$ & \\
\hline $\begin{array}{l}\text { 4. The shift in educational system in the } \\
\text { Philippines needs more funds in } \\
\text { instructional materials that which will } \\
\text { be effective in teaching MTB-MLE and } \\
\text { one of which is the Big Book. It can be } \\
\text { an answer to lessen the concern of our } \\
\text { Department of Education in the } \\
\text { material that will be used to each } \\
\text { locality who will teach MTB-MLE. } \\
\text { Through this, promotion of the } \\
\text { awareness and appreciation of the } \\
\text { people most especially the younger } \\
\text { people in Bato, Camarines Sur will be } \\
\text { achieved. The output can be adopted } \\
\text { by elementary schools in Bato and may } \\
\text { be reproduced by Department of } \\
\text { Education for it may contribute to the } \\
\text { preservation of an age-old tradition as } \\
\text { part of Filipino Culture. }\end{array}$ & $\begin{array}{l}\text { 4. The researcher produced a Big book } \\
\text { which can be used as an educational } \\
\text { material in teaching MTB-MLE to } \\
\text { elementary pupils. This can be } \\
\text { adopted by elementary schools in Bato } \\
\text { and may be reproduced by } \\
\text { Department of Education for it may } \\
\text { contribute to the preservation of an } \\
\text { age-old tradition as part of Filipino } \\
\text { Culture. }\end{array}$ \\
\hline
\end{tabular}

Based on the conclusions, the study recommends the following:

1. Conduct another ethnographic research on other existing traditions in Bato Camarines Sur whereby focusing on the promotion and awareness of the society towards it.

2. Undertake research studies on other genres of folklores in Rinconada Area in order to understand the Bicol culture which mirrors the beliefs of people living in it.

3. Encourage the schools in Bato to integrate folk healing traditions and other genres of folklores in the school curricula to bring the students closer to the culture of their society whereby developing their love for their locale which may also contribute to the preservation of those age-old traditions.

4. Urge the lawmakers to initiate policies in the community that will promote the Bicol folklore most especially in Bato, Camarines Sur.

5. Include some cultural activities in Fiestas, Foundation Celebration and other big events of the society that will be able to help propagate the Bicol culture such as contest on Tigsik, Rawitdawit, Kwentong Suanoy and Reading of some narratives that will promote the culture of Bikol.

6. Build a building that will house the artifacts, artworks, narratives, and other tangible aspects that will help enrich the culture of the locale and of Bicol which will be open for public viewing. 
Ahmad Dahlan Journal of English Studies (ADJES)

Vol. 3, Issue 1, March 2016

7. Plan an annual activity that the government will recognize the folk healers of the society whereby giving them appreciation for being the treasure of the society and must be emulated by people for they extend effort on healing people in the community without asking anything in return.

8. Tie up an activity with National Commission for Culture and Arts (NCCA) and Local Government Units (LGU) and conduct activities and projects such as Workshops on Musical and Dance Bikolnon which will be open to professionals and out of school youth in order for the society to have a deeper root in the place they stay.

9. Publish reading materials such as books, journals, pamphlets, fliers, magazines and newsletters dealing with folk healing traditions and practices and other aspects of folklore added to the collection of Bicol studies.

10. Create a regular activity to conduct exhibits, film shows, theatrical presentations, seminars, conferences that promotes the significance of Bicol lore to modern times.

11. Initiate an extension activities to the community most especially giving gifts to the folk healers of the society giving them proper acknowledgments for being the treasure of the community. 